\title{
Media from Concentrate: Portrayals of Québec Nationalism in Canadian Media
}

\author{
Tim Logan
}

"Diversity of opinion and aggressive news gathering tend to disappear with the disappearance of competition, and public opinion could thereby become more of a hostage to private interests than a master to public policy." 18 These were the words of a young entrepreneur named Conrad Black in 1969. He went on to control over $43 \%$ of Canadian circulation, along with $35 \%$ of the book market. Black argued against anti-concentration regulations by claiming they would constitute government infringement on press freedoms. The 1981 Kent Commission on newspaper ownership summed up the counterargument eloquently: "For the heads of such organizations to justify their positions by appealing to the freedom of the press is offensive to intellectual honesty." "19 Since then, a consensus has formed amongst journalists and those that study them that corporate ownership negatively affects content.

Should we care if newspaper content is being affected? How does this influence happen? How pervasive is it, and to what effect? These are the questions this paper addresses. It begins with a discussion of the media's roles in modern democracies and threats to its ability to fulfil them. From there I move to an overview of the mechanisms of editorial control, the evidence for their existence, and their impacts on content. As there is little discussion of the impacts on coverage of domestic nationalism in the literature, I examine Québec's Charter of Values to help fill this gap. Specifically, I ask two questions: what is the impact of ownership on media

\footnotetext{
${ }_{18}$ John Miller, Yesterday's News Why Canada's Daily Newspapers Are Failing Us (Halifax 1998), 80.

${ }^{19}$ Canada. Royal Commission on Newspapers and Tom Kent, Royal Commission on Newspapers: [Report] (Hull, 1981).
} 
coverage of Québec nationalism? And to what extent is this impact mediated by market characteristics? I answer these questions with structural and manifest analyses of three Canadian newspapers: the Globe and Mail, owned by the Thomson family, and the National Post and Ottawa Citizen, two corporate papers owned by Postmedia. I have two hypotheses: first, that the Post and the Citizen will have a more conservative outlook on the Charter of Values than the Globe, and second, that the conservative impact of ownership on the Citizen will be less than that on the Post.

\section{News media and democracy}

If content is indeed affected by ownership, then Canada is in a precarious situation today, the five largest corporations (Postmedia, Woodbridge, Quebecor, Power Corp, and Torstar) control $82 \%$ of daily newspaper circulation. In economics, it is standard to consider a market at risk of harm from oligopoly when the top four firms control more than $50 \%$ of the market, and Canada is well over this limit: Postmedia and Quebecor alone control 54\% of daily circulation. ${ }^{2021}$ At the national level, two-firm concentration is $100 \%$, with only the National Post and the Globe and Mail publishing. (The consensus among media scholars is that levels as low as $20 \%$ are cause for concern). ${ }^{22}$ Newspaper choices are thus very limited, yet also very relevant $-73 \%$ of Canadians read a daily newspaper at least once a week. ${ }^{23}$ This large sphere of influence has profound implications for Canadian politics given the media's roles in modern democracies.

\footnotetext{
${ }^{20}$ Robert G. Picard, Measures of Concentration in the Daily Newspaper Industry (1988), 62.

${ }^{21}$ Perry Rand Dyck, Canadian Politics (Toronto 2012), 157.

${ }^{22}$ Robert G. Picard, Press Concentration and Monopoly: New Perspectives on Newspaper Ownership and Operation, (Norwood 1988), 204.

${ }^{23}$ Faq | Newspapers Canada, Newspapers Canada (accessed 18 November 2013).
} 
First, the media function as watchdogs, observing public behaviour and watching for transgressions of social norms, morals, and laws. ${ }^{24}$ Their focus is very wide, from politicians to businesses to other media sources and everything in-between. If certain parties are getting 'free rides' from the media, then they may not be held accountable for their actions - would Watergate have happened without Bob Woodward and Carl Bernstein? The threat of exposure and public shaming also acts as a disincentive towards bad behaviour.

Second, and perhaps most importantly, the media function as educators. As Johanna Dunaway writes, the media ought to "provide the public with sufficient information for evaluating leaders and governance and for making electoral choices. ${ }^{, 25} \mathrm{We}$ obtain nearly all of our political information from the media, and as technology has enabled more people to participate in politics and be heard, being well-informed has become more and more important. And with information especially, quality is far more important than quantity. ${ }^{26}$ The unity of a country may even depend on this information and the discussion it creates, as it did in Canada in 1980 and 1995, and as it may in Scotland in 2014.

Third, the media facilitate and mediate these discussions. Modern societies are large and complex, as are the issues facing them, which mean that a division of labour is almost certainly necessary. Few people have the time to thoroughly research these complex matters, so, we rely on the media to present the strongest available evidence on each side and then we make our decisions based on that. This need for public deliberation suggests a need for "professional

\footnotetext{
${ }^{24}$ Herbert J. Gans, Deciding What's News: A Study of Cbs Evening News, Nbc Nightly News, Newsweek, and Time, (New York 1979), 293.

${ }_{25}^{25}$ Johanna Dunaway, Markets, Ownership, and the Quality of Campaign News Coverage (2008): 1193.

${ }^{26}$ Michael Baranowski, Navigating the New : A Political Media User's Guide, 3.

Miller, Yesterday's News, 81.
} 
communicators" - in other words, a professional and dedicated media. ${ }^{27}$ In addition to influencing the quality of these discussions, the media also play a large role in determining the subjects themselves.

The fourth role of the media is that of the agenda-setter. Agendas are "a ranking of the relative importance of various public issues," and through their choice of topics, the media exerts a large amount of control over what is on people's minds. ${ }^{28}$ While they don't always lead public opinion (since some issues like unemployment tangibly affect many people) they do in many cases simply because some issues affect only a small group. ${ }^{29}$ In these cases, the media will necessarily lead public opinion because without coverage there would be no thought given to the matter and therefore no opinion would form.

So, the media determine what information we have, the arguments we see, and the topics $d u$ jour. The net result of this is that they have a powerful impact on public opinion. While some scholars argue to the contrary ${ }^{\dagger}$ most of this work uses data from a time before concentrated media and interpretive journalism, which are the current context in Canada. As we will soon see, concentrated media tends to reduce the diversity of information and viewpoints available - this necessarily shapes public opinion in the long run, because information is the key to forming opinions. Agenda-setting also has 'priming' impacts: different sets of words trigger different mental associations and thus creates different opinions. ${ }^{30}$ For example, contrast "the mission in Afghanistan" with "the war in Afghanistan": one emphasizes purpose and a desire to help, the

\footnotetext{
${ }^{27}$ Benjamin I. Page, Who Deliberates?: Mass Media in Modern Democracy (Chicago 1996), 106.

${ }^{28}$ James Dearing, qtd. in Stuart Neil Soroka, Agenda-Setting Dynamics in Canada (Vancouver 2002$), 6$.

${ }^{29}$ Ibid, 10, 20.

'Soroka's book on agenda-setting reviews the important works advancing this hypothesis.

${ }^{30}$ nePaul W. Nesbitt-Larking, Politics, Society, and the Media, (Peterborough 2007), 335.
} 
other emphasizes violence. A by-product of this is that media influence peaks when a new issue or sub-issue appears and there is an opportunity to frame it in a certain way. ${ }^{31}$ The extent to which the media fulfils its roles therefore holds a large amount of sway over public opinion and politics as a whole. So, how well are these roles being performed?

\section{Ownership and the roles of the media}

Over the past twenty years, media in Canada and around the world have fallen victim to tabloidization and trivialization. Competition from supermarket gossip magazines such as People and $U s$ and a declining emphasis on civic responsibility have bitten into their readership; in an effort to hold their place, newspapers' entertainment sections have swollen while their substantive news coverage has gradually been replaced with shallower, easily-digested 'human interest' stories. This shift was on full display in 1994 when the New York Times quoted the National Enquirer while reporting on the trial of O.J. Simpson. The very definition of what qualifies as news has radically changed, and the quantity of political information we receive has declined considerably.

So too has the quality of this information. Objectivity, the standard of excellence in the mid- $20^{\text {th }}$ century, has been eclipsed by interpretive reporting, where factual reporting is accompanied by subjective analysis. This creates a situation in which "people still trust newspapers ... and are largely unaware of the political diet being served up along with these other dishes." 32 Declining revenues from readership and advertising have led to staffing cuts and amongst the first to go are the political correspondents. When combined with the rise of

\footnotetext{
${ }^{31}$ Soroka, Agenda-Setting Dynamics in Canada, 104.

${ }^{32}$ David Taras, Power and Betrayal in the Canadian Media (Peterborough 2001), 217.
} 
punditry and political activism amongst the journalists themselves, we end up in a situation of 'activist presses', wherein the press themselves become politicized actors, filling the gaps in their coverage with argumentation and opinion. ${ }^{33}$ Now, this isn't necessarily a bad thing: the news media in America has seen all of these changes, yet their marketplace of ideas still works "reasonably well (...) [Because] there is sufficient competition and diversity in the information system." 34

Canada's information system, on the other hand, is much more concentrated and therefore less competitive - so, how does concentration relate to diversity? There is disagreement on this in the literature - Hale, for example, finds no significant difference in editorials between chain and non-chain papers. ${ }^{35}$ Some of the smaller papers purchased by Hollinger seemed to have actually improved in this field after changing hands. ${ }^{36}$ Economies of scale could make more resources available to reporters and allow for better-researched stories, and maybe the organizational distance created between reporters and the new executives result in a "divorce of ownership and control. ${ }^{, 37} \mathrm{~A}$ larger, more powerful conglomerate might be better-equipped to stand up to manipulative advertisers. ${ }^{38}$ And competition doesn't insure diversity: McComb's 1988 analysis of competing papers in Winnipeg and Montreal shows a remarkably high degree of similarity. ${ }^{39}$

\footnotetext{
${ }^{33}$ Page, Who Deliberates? 116.

${ }^{34}$ Ibid, 124.

${ }^{35}$ Dennis F. Hale, Editorial Diversity and Concentration (Norwood 1988).

${ }^{36}$ James P. Winter, Democracy's Oxygen: How Corporations Control the News (Montreal 1997), 34.

${ }^{37}$ Nesbitt-Larking, Politics, Society, and the Media, 108.

${ }^{38}$ Ibid, 109.

${ }^{39}$ Maxwell E. McCombs, Concentration, Monopoly, and Content (Norwood 1988).
} 
Unfortunately, these outlooks seem overly optimistic. Empirically, there is "plentiful evidence" from around the world that concentrated ownership leads to lower quality and less diversity. ${ }^{40}$ Studies from the UK show the intervention of Rupert Murdoch into the content of his holdings there, while evidence from Italy shows that Silvio Berlusconi used his television empire to gain power and hold on to it. ${ }^{41}$ Bagdikian chronicles many interventions by owners in the United States, ranging in size from small-town Delaware to the support of McCarthyism by the Hearst chain, ${ }^{42}$ while Dunaway finds that corporate ownership decreases issue coverage in Congressional elections. ${ }^{43}$ Hallock shows a decrease in local content due to corporate ownership and reviews other similar findings. ${ }^{44}$ Returning to Canada, the Kent Commission also notes negative impacts of corporate ownership on diversity. ${ }^{45}$ Like McComb, Candussi examines Montreal and Winnipeg, but after one paper in each town closed, leaving monopolies in both towns. He finds small but significant decreases in quality and newsholes (the space devoted to news coverage) ${ }^{46}$ Soroka and Fournier, in an anonymous survey of Canadian journalists, find that $86 \%$ of them believe that concentrated ownership lowers quality and diversity of content. ${ }^{47}$ It is fairly clear that concentrated ownership has real impacts on newspaper content - how, then, does this influence happen?

\section{Causal links between ownership and content}

\footnotetext{
${ }^{40}$ Gillian Doyle, Media Ownership: The Economics and Politics of Convergence and Concentration in the UK and European Media (London 2002), 19.

${ }^{41}$ Ibid.

${ }^{42}$ Ben H. Bagdikian, The Media Monopoly (Boston 1992), 41-42.

${ }^{43}$ Dunaway, Markets, Ownership, and the Quality of Campaign News Coverage.

${ }^{44}$ Steven M. Hallock, Editorial and Opinion: The Dwindling Marketplace of Ideas in Today's News (Westport 2007).

${ }^{45}$ Canada. Royal Commission on Newspapers and Kent.

${ }^{46}$ Winter Candussi, Monopoly and Content in Winnipeg (Norwood 1988).

${ }^{47}$ Stuart Soroka and Patrick Fournier, With Media Ownership, Size Does Matter, 12 February 2003.
} 
David Radler, former president of Hollinger Incorporated and Conrad Black's right-handman, once said of the newspaper empire he oversaw: "I will ultimately determine what the papers say and how they're going to be run. ${ }^{48}$ Radler's statement confirmed what Warren Breed wrote over fifty years ago: "Every newspaper has a policy, admitted or not." ${ }^{49}$ Some owners, like Black, openly and explicitly dictate editorial policy to their employees. ${ }^{50}$ Black "constantly injected political partisanship" into his acquisitions, and this culminated in his founding of the National Post in a publicly-trumpeted attempt to "unite the right." ${ }^{.51}$ This overt trend continued even after Black sold his holdings to Israel Asper's CanWest in 2000 - in fact, the decrees only became more explicit. In 2001, CanWest subsidiaries across the country were ordered to run editorials written at company headquarters in Winnipeg, leading to a by-line strike at several CanWest papers, including the Montréal Gazette. Breaches of explicit policy are generally treated very harshly - for example, when the then-CanWest paper the Ottawa Citizen ran an editorial calling for the resignation of Jean Chrétien, one of Asper's personal friends, Asper fired its long-standing publisher. The resulting furor, helped along by a report from the Globe and Mail on plans to centralize news content (an example of media performing its watchdog function towards media sources), resulted in CanWest abandoning its explicit dictates. ${ }^{52}$

Editorial policy remained, however, but now it was enforced indirectly, through what Breed calls "social control." Through reading their own newspaper, noticing patterns of feedback and corrections from the editors, story assignment, attending newsroom conferences with the

\footnotetext{
${ }^{48}$ Winter, Democracy's Oxygen, 86.

${ }^{49}$ Warren Breed, Social Control in the Newsroom: A Functional Analysis (1955), 327.

${ }^{50}$ Pamela J. Shoemaker and Stephen D. Reese, Mediating the Message in the 21st Century: A Media Sociology Perspective (New York 2013), 159.

${ }^{51}$ Marc Edge, Asper Nation: Canada's Most Dangerous Media Company (Vancouver 2007), 3.

${ }^{52}$ Ibid, 6-7.
} 
publisher and other executives, and occasionally receiving rebukes from their superiors where necessary, reporters develop an understanding of what is accepted and what isn't through a process of 'policy osmosis'. There are powerful incentives for staff to follow this policy promotions, perks, scoops, and leads all depend on writing the company line. And given the focus on costs that corporate owners universally bring, there are lots of opportunities for 'squeaky wheels' to be dismissed. ${ }^{53}$ New hires are likely to conform to policy already as people tend to hire those that are similar in disposition to themselves. Executives hire similar senior staffs, who in turn hire similar editors, and so on down the ranks. Thus, "news becomes largely a management product, from hiring and promotion to assignment, framing, sourcing, editing, placement and so forth, in a process of newsroom socialization." 54

The clearest way the ownership's policy manifests itself in content is through the pulling of stories that contravene it. Usually this is done for vague reasons such as time or space constraints, but the message is sent to the reporter nonetheless. Less obvious but more common is a practice known as "slanting," which involves "omission, differential selection and preferential placement,"55 along with the selection and shaping of quotations and facts used in the story itself. ${ }^{56}$ For instance, CanWest used to replace all references to Palestinian 'militants' in Middle Eastern newswires with Palestinian 'terrorists'. 57

\footnotetext{
${ }^{53}$ Breed, Social Control in the Newsroom: A Functional Analysis, 330. Shoemaker and Reese, Mediating the Message 159.

Winter, Democracy's Oxygen, 100.

${ }^{54}$ Ibid, 139.

${ }_{55}^{55}$ Breed, Social Control in the Newsroom: A Functional Analysis, 327.

${ }^{56}$ Page, Who Deliberates? 112-3.

${ }^{57}$ Edge, Asper Nation, 135.
} 
By far the most subtle and insidious form of control happens through the journalists themselves - Gans calls this an "anticipatory avoidance of pressure" and it is essentially unconscious self-censorship. ${ }^{58}$ Journalists, having learned the policy through osmosis, decide that it isn't worth the effort to buck the trend, and simply ignore any story ideas that contravene newsroom norms - it is rare for experienced journalists to be put back into line by the "invisible hand" of control because, in effect, they have internalized it. ${ }^{59}$ The power of this effect should not be underestimated: $25 \%$ of American journalists surveyed by Kohut admitted to have avoided a newsworthy story purposely and $41 \%$ of them admitted to self-censorship, yet only one-fifth reported overt rebukes from their superiors. ${ }^{60}$ Soroka and Fournier's survey of Canadian journalists reveals similar trends: more than $20 \%$ of journalists overall believe that the owner's views influence news content, peaking at between $67 \%$ and $83 \%$ at three Postmedia papers (Postmedia is the successor to CanWest). While obedience to policy is not automatic and has been shown to be mediated by professional journalistic norms, it nevertheless remains highly significant. $^{61}$

These impacts spread across many areas of reporting. Hallock, as already mentioned, finds a decrease in local coverage with corporate ownership, though this may be more due to a focus on capturing circulation and increasing revenue through entertaining story material while simultaneously slashing staffing levels to cut costs. Page shows that corporate media are more likely to take a hawkish stance on foreign policy. ${ }^{62}$ Meanwhile, Dyck argues that conglomerateowned media in Canada are likely to have a pro-corporate bias and that most of these

\footnotetext{
${ }^{58}$ Gans, Deciding What's News, 270.

${ }^{59}$ Eric Fenn Elbott, The Giants in Our Midst (1992), 5.

${ }^{60}$ Andrew Kohut, Self-Censorship: Counting the Ways (2000), 42-3.

${ }^{61}$ Breed, Social Control in the Newsroom: A Functional Analysis, 326.

${ }^{62}$ Page, Who Deliberates? 116.
} 
conglomerates have many diverse interests outside of media. ${ }^{63}$ The Irving family in New Brunswick is an excellent example of this. They hold all of the English-language daily newspapers in the province, and, like most media families, the Irvings have other large interests among other things, they own the largest oil refinery in Canada, forestry operations, and a frozen foods company. Their papers are known for failing to report on the sometimes-questionable activities of their sister companies. However, there is surprisingly no work done on the impacts of policy on coverage of domestic nationalist movements in Canada, especially given the key role of the media in the 1995 sovereignty referendum.

\section{Research design and methodology}

This paper examines the portrayals of Québec nationalism in Canadian media, specifically with reference to the recently-proposed «Charte des valeurs québécoises», or Charter of Values. The Charter, tabled in the National Assembly on 10 September 2013, has been interpreted as an attempt by the sovereigntist government of Québec to reignite the sovereignty movement and win support in rural Québec. As such, this makes it an ideal candidate for study, for two reasons. First, as noted by Soroka, the media's power to shape opinion on any given issue declines over time, and not only has this debate been relatively quiet over the past few years, but the Charter is a distinct sub-issue. This means that the media's power to frame the issue should be at its zenith, so their attempts to do so should be more obvious. Second, this is the first time Québec nationalism has achieved such a high level of salience with two national papers in existence: until 1998, the Globe was the only truly national paper in Canada.

${ }^{63}$ Dyck, Canadian Politics, 157. 
I use the Globe as a baseline against which to compare the other two papers. It is regarded as being fairly centrist, which is sensible given that for most of its history it has had to appeal to the entire population. Moreover, the Thomsons have long taken a 'hands-off' approach to its management. ${ }^{64}$ As centrists have less of a penchant for ideological bent, I expect to see the Globe use a fairly neutral tone in reference to the Charter.

The obvious counter to the Globe is the National Post, being the only other national paper. However, the Post's parent company, Postmedia, has a long history of editorial meddling - its origins are in the distinctly conservative Southam newspaper empire, which was then bought by the radically conservative Conrad Black, and then sold to the similarly conservative Asper family. After CanWest went bankrupt, its print arm was spun off into Postmedia, a buying group assembled under the leadership of National Post CEO Paul Godfrey. His principle backers in the deal were two large and very conservative American hedge funds, Silver Point Capital and GoldenTree Asset Management. Godfrey himself is also quite conservative - he was close to Frank Miller, former Progressive Conservative premier of Ontario, and worked for Sun Media, another conservative media group, in the early 90s. Postmedia's long history of conservatism and both direct and indirect editorial control make its papers ideal candidates for studying the effects of ownership. As conservatives in Canada have traditionally been extremely hostile towards Québec nationalism, I expect to find both a very negative tone towards the Charter, and significantly more content published on it.

\footnotetext{
${ }^{64}$ Nicholas Kôhler and Anne Kingston, Canada's Rich, Troubled Thomson Family, The Canadian Encyclopedia http://www.thecanadianencyclopedia.com/en/article/canadas-rich-troubled-thomson-family/ (accessed 18 November 2013).

Canadian Newswire, "Woodbridge Acquires Direct Ownership of the Globe and Mail", Canadian Newswire http://www.newswire.ca/en/story/667019/woodbridge-acquires-direct-ownership-of-the-globe-and-mail (accessed 27 November 2013).
} 
While the Ottawa Citizen is not a national paper and so is not directly comparable to the Globe and the Post, it is also a Postmedia paper and should therefore have a similar level of conservative influence within its organizational structure. It differs, however, in that it is essentially a monopoly paper. As with the Globe, this should mean that it will moderate its stance in order to appeal to a broad segment of the population and prevent the entry of any new competitors. Therefore, comparing the Citizen to the Globe and Post will allow me to examine the extent to which market characteristics mediate ownership influences. Specifically, I hypothesize that the conservative-owned National Post and Ottawa Citizen will take a more conservative stance towards the Charter than will the Globe and Mail, although the impact of ownership on the Citizen will be moderated by market considerations.

To test my hypothesis I will use three content analyses: one structural and two manifest. The structural analysis is a count of articles and editorials published, as retrieved from a ProQuest database search limited to the period of 11 September-11 October $2013 .^{\dagger}$ I discarded passing mentions and reclassified articles and editorials where necessary. The first manifest analysis is a coding of photos of PQ MNAs from the first 10 publishing days of the period. There are three possible categories for each photo, based on how the subject is depicted: "aggressive" (e.g., hostile, smug), “explaining," (e.g., calm, open to discussion) or "neither." As physical copies of the Citizen were unfortunately not available to me and PressDisplay only archives the past 30 days of it, it is excluded from this analysis. The third and final analysis is an automated dictionary-based measure of tone, using Soroka's Lexicoder software (available at

\footnotetext{
$\dagger$ The exact search term was equal to "(Quebec Charter of Values)", minus the quotations. The dates were chosen to represent a calendar month after the tabling of the Charter.
} 
www.lexicoder.com) and the accompanying Lexicoder Sentiment Dictionary. Past work has shown results from this combination to align closely with human coding. ${ }^{65}$ The articles and editorials are coded separately, accounting for negations. The measure of tone is equal to the average of (positive - negative - negated positive + negated negative)/(word count) for each piece. My working hypotheses are as follows:

WH1: The National Post will run the most articles and editorials on the Charter, followed by the Ottawa Citizen and then the Globe and Mail.

WH2: Photos in the National Post will portray the PQ as more aggressive than those in the Globe and Mail.

WH3: News articles and op-eds in the National Post will be the most negative in tone, followed by the Ottawa Citizen and then the Globe and Mail.

\section{Results}

\begin{tabular}{|c|c|c|c|}
\cline { 2 - 4 } \multicolumn{1}{c|}{} & National Post & $\begin{array}{c}\text { Ottawa } \\
\text { Citizen }\end{array}$ & $\begin{array}{c}\text { Globe and } \\
\text { Mail }\end{array}$ \\
\hline $\begin{array}{c}\text { News articles } \\
\text { published } \\
\begin{array}{c}\text { Editorials } \\
\text { published }\end{array}\end{array}$ & 36 & 28 & 39 \\
\hline
\end{tabular}

There was no significant difference in the number of news articles published between the three papers. The Globe published significantly more editorials than either the Post or the Citizen $(\mathrm{P}<.05)$

\footnotetext{
${ }^{65}$ Lori Young and Stuart Soroka, Affective News: The Automated Coding of Sentiment in Political Texts (2012).
} 


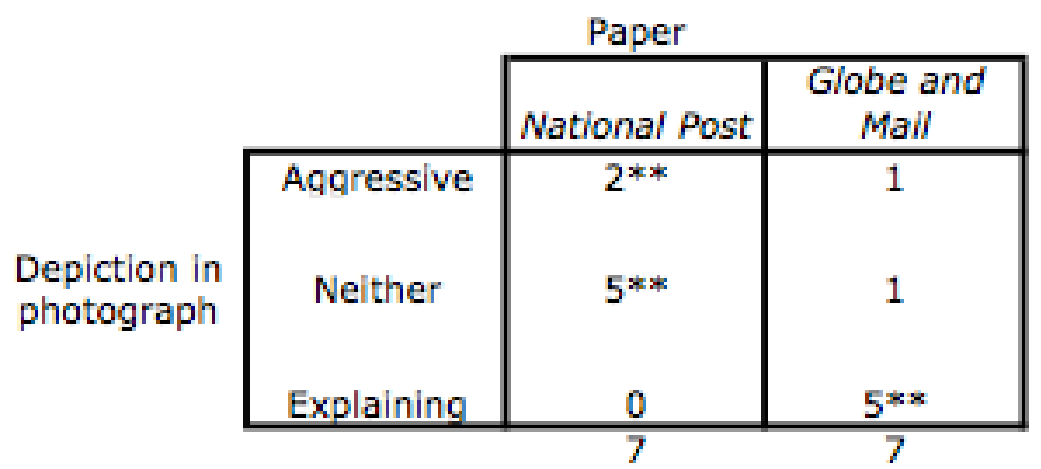

The Post published significantly more photos depicting the PQ as aggressive or neither, while most of the photos in the Globe showed the PQ in an explaining fashion (all $\mathrm{P}<.01$ ).

\begin{tabular}{|c|c|c|c|c|}
\hline & \multicolumn{3}{|c|}{ Paper } \\
\hline & & National Post & $\begin{array}{l}\text { Ottawa } \\
\text { Citizen }\end{array}$ & $\begin{array}{c}\text { Globe and } \\
\text { Mail }\end{array}$ \\
\hline \multirow{2}{*}{ average tone } & News articles & $-0.16 \%$ & $-0.11 \%$ & $-0.47 \%$ \\
\hline & Editorials & $+0.69 \%$ & $-1.6 \%$ & $-0.76 \% *$ \\
\hline
\end{tabular}

There was no significant difference in tone in news articles between the three papers. The editorials published in the Globe were significantly more negative in tone than those in the Post $(\mathrm{P}<.5)$; the sample of editorials from the Citizen was not large enough to establish significance.

\section{Analysis}

$\underline{\mathrm{WH} 1}$

While largely not significant, the preliminary results of my structural analysis do not confirm my hypothesis. Rather, they offer support for Candussi's hypothesis that corporate media holdings have less substantive news coverage than non-corporate ones. However, average word counts as measured by Lexicoder were significantly higher for both Postmedia papers in both categories, thus offering some support for my hypothesis. This may be a reflection of what 
appears to be the diminished newsholes of the Postmedia papers. ${ }^{\dagger}$ Smaller newsholes in Postmedia papers may imply that word count may be a better structural measure of importance in situations of corporate ownership than number of pieces run - this could be a starting point for further analysis in the future. Overall this analysis neither confirms nor disconfirms my hypothesis.

\section{$\underline{\mathrm{WH} 2}$}

Though the number of cases for each paper was relatively small, the results of my first manifest analysis are highly significant. This result offers preliminary confirmation of the first part of my hypothesis, which the conservative ownership of the Post would result in its content being significantly more conservative than that of the Globe. More photos from both papers, along with the photos from the Citizen, would likely confirm it more firmly.

Additionally, it should be noted that the Post ran a fairly derogatory cartoon of Pauline Marois on its front page on 11 September, whereas the Globe ran an infographic illustrating what symbols would and would not be acceptable under the Charter. These were not included in the analysis as they were not photos, but they are nonetheless indicative of overall stances. The prevalence of cartoons on the front pages of both the Post (and potentially the Citizen), as opposed to the Globe, could be highly informative, given the explicitly ideological nature of political cartoons and the approvals needed to run them in that location. Also of interest is the density with which the Post ran photos - it stopped carrying photos alongside its articles three days before the Globe. Thus, the 'intensity' of the coverage of the Charter was higher in the Post

\footnotetext{
${ }^{\dagger}$ While not rigorously collected, passing observations from the coding of photos in the Post suggest that this is indeed the case with at least that paper. There seemed to be significantly more human-interest stories in the Post than in the Globe.
} 
than it was in the Globe, which may also imply that corporate papers have a shorter 'attention span' than non-corporate ones. This analysis constitutes a moderate confirmation of my hypothesis.

$\underline{\mathrm{WH} 3}$

My second manifest analysis disconfirms my hypothesis - none of the differences in tone were significant, save the editorial tone difference between the Globe and the Post, which ran in an opposite direction to my expectations. This could imply that there is no relation in the broader population, which is unlikely given the preliminary significance of the results from the first manifest analysis. It is also conceivable that I wrongly predicted the direction of the effect; perhaps the centre is more concerned with Québec nationalism than the conservatives. Again, this is unlikely given the significance of my previous results. A third possibility is that this is a result of a small sample size, which is very well possible, especially given the number of editorials that were sampled; samples for analyses like this one are often much higher.

The fourth and most likely possibility is that confining the dictionary count to words cooccurring or occurring very close to "Charter" and the names of key PQ members would increase measurement validity and reliability to the point where significant results are obtainable. This is the approach used by Soroka, Cutler, Stolle, and Fournier in their study of news coverage around the federal parties and leaders during the 2011 Canadian election. ${ }^{66}$ The general count I performed may have picked up tonal words and phrases not used specifically in reference to the Charter, which would negatively impact measurement validity and help to explain why

\footnotetext{
${ }^{66}$ Stuart Soroka et al., Capturing Change (and Stability) in the 2011 Campaign, (2011).
} 
significant results were not obtained with a method that has proven highly effective in the past. There is, however, indication that the procedure was functional to an extent as the editorials were consistently coded as being more tonal than the news coverage. This analysis only weakly disconfirms my hypothesis because of questions surrounding measurement validity and reliability.

\section{Conclusion}

Overall, the results of my analyses moderately support my hypothesis: it appears that the influence exercised on newspaper content by the political views of owners extends to coverage of domestic nationalism in addition to the other areas where its impacts have already been explored. Given the negative reactions engendered by explicit decrees of editorial policy from both journalists and the public in the past, social control is the most plausible causal mechanism. This conclusion implies that we should be seriously concerned for Canadian politics, given the highly-concentrated nature of its media holdings, especially at the national level. If concentration is not reversed, newsholes and substantive coverage may continue to be reduced, thus imperilling the ability of Canadian news media to fulfil their roles, and, by extension, threatening the quality of Canadian democracy in the larger sense. In this way, Canadian news media resemble fruit juice made from a frozen concentrate: only satisfying if you have never tasted the real thing. 


\section{Bibliography}

"Faq | Newspapers Canada", Newspapers Canada (accessed 18 November 2013).

Bagdikian, Ben H. The Media Monopoly. 4th ed. Boston: Beacon Press, 1992.

Baranowski, Michael. Navigating the News : A Political Media User's Guide.

Breed, Warren. "Social Control in the Newsroom: A Functional Analysis." Social Forces 33, no. 4 (1955): 326-335.

Canada. Royal Commission on Newspapers. and Tom Kent. Royal Commission on Newspapers : [Report]. Hull, Que.: The Commission, 1981.

Candussi, Winter. "Monopoly and Content in Winnipeg." In Press Concentration and Monopoly : New Perspectives on Newspaper Ownership and Operation, edited by Robert G. Picard, ix, 231 p. Norwood, N.J.: Ablex Pub. Corp., 1988.

Doyle, Gillian. Media Ownership : The Economics and Politics of Convergence and Concentration in the Uk and European Media. London ; Thousand Oaks Calif.: SAGE, 2002.

Dunaway, Johanna. "Markets, Ownership, and the Quality of Campaign News Coverage." The Journal of Politics, no. 70 (2008): pp 1193-1202.

Dyck, Perry Rand. Canadian Politics. Concise 5th ed. Toronto: Nelson Education, 2012.

Edge, Marc. Asper Nation : Canada's Most Dangerous Media Company. Vancouver: New Star Books, 2007.

Elbott, Eric Fenn. "The Giants in Our Midst." Media Ethics 4, no. 2 (1992).

Gans, Herbert J. Deciding What's News : A Study of Cbs Evening News, Nbc Nightly News, Newsweek, and Time. 1st ed. New York: Pantheon Books, 1979.

Hale, Dennis F. "Editorial Diversity and Concentration." In Press Concentration and Monopoly : New Perspectives on Newspaper Ownership and Operation, edited by Robert G. Picard, ix, 231 p. Norwood, N.J.: Ablex Pub. Corp., 1988.

Hallock, Steven M. Editorial and Opinion : The Dwindling Marketplace of Ideas in Today's News Democracy and the News,. Westport, Conn.: Praeger, 2007.

Kôhler, Nicholas and Anne Kingston, "Canada's Rich, Troubled Thomson Family", The Canadian Encyclopedia http://www.thecanadianencyclopedia.com/en/article/canadasrich-troubled-thomson-family/ (accessed 18 November 2013). 
Kohut, Andrew. "Self-Censorship: Counting the Ways." Columbia Journalism Review 39, no. 1 (2000).

McCombs, Maxwell E. "Concentration, Monopoly, and Content." In Press Concentration and Monopoly: New Perspectives on Newspaper Ownership and Operation, edited by Robert G. Picard, ix, 231 p. Norwood, N.J.: Ablex Pub. Corp., 1988.

Miller, John. Yesterday's News Why Canada's Daily Newspapers Are Failing Us. Halifax, N.S.: Fernwood Pub.,, 1998.

Nesbitt-Larking, Paul W. Politics, Society, and the Media. 2nd ed. Peterborough, Ont.: Broadview Press, 2007.

Newswire, Canadian, "Woodbridge Acquires Direct Ownership of the Globe and Mail", Canadian Newswire http://www.newswire.ca/en/story/667019/woodbridge-acquiresdirect-ownership-of-the-globe-and-mail (accessed 27 November 2013).

Page, Benjamin I. Who Deliberates? : Mass Media in Modern Democracy American Politics and Political Economy. Chicago: University of Chicago Press, 1996.

Picard, Robert G. "Measures of Concentration in the Daily Newspaper Industry." Journal of Media Economics 1, no. 1 (1988): 61-74.

Picard, Robert G. Press Concentration and Monopoly : New Perspectives on Newspaper Ownership and Operation Communication and Information Science. Norwood, N.J.: Ablex Pub. Corp., 1988.

Shoemaker, Pamela J. and Stephen D. Reese. Mediating the Message in the 21st Century : A Media Sociology Perspective. Third edition. ed. New York: Routledge, 2013.

Soroka, Stuart, Fred Cutler, Dietlind Stolle and Patrick Fournier. "Capturing Change (and Stability) in the 2011 Campaign." OPTIONS POLITIQUES, (2011): 70.

Soroka, Stuart and Patrick Fournier. "With Media Ownership, Size Does Matter." The Globe and Mail, 12 February 2003.

Soroka, Stuart Neil. Agenda-Setting Dynamics in Canada. Vancouver: UBC Press, 2002.

Taras, David. Power and Betrayal in the Canadian Media. Updated ed. Peterborough, Ont.: Broadview Press, 2001.

Winter, James P. Democracy's Oxygen : How Corporations Control the News. Montreal: Black Rose Books, 1997.

Young, Lori and Stuart Soroka. "Affective News: The Automated Coding of Sentiment in Political Texts." Political Communication 29, no. 2 (2012): 205-231. 